\title{
A Critical Review on the Differences between an Art Student and a Design Student in their Critical Thinking and Learning Style
}

\author{
Weaam Ahmed ElMasry Abdellatif ${ }^{1)}$ Esraa Mohamed ElMoatasem ElKhodary ${ }^{2)}$
}

1) Lecturer at the Faculty of Arts \& Design, Modern Sciences and Arts University

2) Lecturer at the Fashion Department, Faculty of Arts \& Design, Modern Sciences and Arts University

\section{KEY WORDS:}

Critical Thinking, David Kolb's model (Experiential Learning Theory), Reflective practice.

\begin{abstract}
:
Creative thinking is a process of a specific thought that improves the ability of creativeness. At one's optimal state, the process enables the mind to generate new ideas and to think deliberately in different ways. In other words, it is a series of intellectual actions that produce changes and developments of a thought. When comparing between an Art student and a Design student, their creative thinking process may differ from one to another and that is due to their tasks and responsibilities that each of them have to fulfill. Their creative and critical thinking might have similarities at the beginning of their education, since they are still exploring their talent, but students at their final year or even post graduate students might be totally different from one another. David Kolb published his learning styles model which gave rise to terms such as "experiential learning theory" (ELT), and "learning styles inventory" (LSI). Kolb's learning styles model and experiential learning theory are today acknowledged by academics, teachers, managers and trainers as truly influential and fundamental concepts towards our understanding and explaining human learning behavior. Kolb's model offers both a way to understand individual learning styles, and also an explanation of a cycle of experiential learning that applies to all learners.

In this paper, the research suggests that applying David Kolb's experiential learning theory (ELT) would differentiate between an Art student and a Design student which could help in guiding the students to their strength point and to discover themselves as early as possible, besides helping the educator to design a flexible design course which could match both types and make use of the best of them. The research methodology is based on a theoretical approach covering Kolb's model, critical thinking and a case study on students enrolled at the Faculty of Arts and Design, MSA University. All levels of students were covered in 4 majors as well as a comparable study applied to a sample of students who go through the case study five years ago and were asked to redo the questionnaire once more to compare the results.
\end{abstract}




\section{INTRODUCTION}

It has been observed by Schon $(1987,2013)$ that the learning process that is developed in a studio is called "reflection in action' but yet according to Waks, design education hasn't flourished since then $(1999,2001)$. Lately, design educators have started to study the characteristics of learning styles which can be used to improve the learning style of both Art and design students (Kvan,T. et.al, 2005, Uluoglu,B., 2000, Demirbas, O.O., 2001 and Demirbas, O.O et.al, 2003). The methods used in learning and teaching in design education aims to create a balance between the creative process and the critical awareness to develop a proposition. The aim of each student is to create a unique, non-repetitive piece of work while putting into consideration the inquiry he is fulfilling. The learning process is characterized by continual dialogue where students learn from sharing information with one another and with the instructors and finally from the critiques they receive from Jury members (Demirbas, O.O. et al., 2003 and Newland, P. et al 1987).

As for the graduates, they are expected to be highly motivated, technically competent and mentally prepared to deal with ideas at a professional level. While they are undergraduates, it is the duty of an educator to shape and guide the students in order for them to be able to understand and apply the knowledge, skills, process of theories and this is to provide the student with a balanced synthesis between the artistic, technological and humane aspects of the professions (Demirbas, O.O et al., 2007).

Understanding the learning style of students has a wide range of possibilities in education. This wide range may vary from classifying the learning preference to detecting potential learning difficulty at an early stage of a student (Slaats, A. et al 1999). Some educators feel the urge to adjust their ways of teaching to meet students' expectations while instead they should accommodate to teacher's teaching style (Dunn, R. et al., 1975). In this paper investigates the differences between an art student and a design student in order to see whether art \& design education is aligned with the ELT of Kolb or not.

\section{OVERVIEW AND BACKGROUND 1.CRITICAL THINKING}

From different areas in different fields, researchers tend to relate critical thinking with the development of a person's cognitive and intellectual capacities which may include both skills and attitudes (Indrasiene, V. et al., 2019). The main aspect of critical thinking is the ability to question, explore, and change the established beliefs of your own and others. So in other words, critical thinking is self-directing, self-disciplining, self-monitoring, and self- $\neg$ corrective thinking (Paul, R. et al., 2006).

As compiled by Montana-Hoyos (2011), Critical thinking refers to a collection of overlapping of mental activities. Such activities may vary between intuiting, clarifying, reflecting, connecting, inferring, judging, and so on. These activities are brought together to evaluate the credibility, quality, impact, significance, usefulness or desirability of an entity on the basis of an implicit or explicit value system. The entity being evaluated can be considered as a knowledge claim, a research article, a work of art, a funding proposal, a social practice, an institution, a person, and so on, with the factors relevant for the evaluation varying accordingly. Creative and critical thinking skills have the capability to provide feedback to one another, which in other words according to Montana-Hoyos (2011) "becoming complementary and interdependent in an effective thinking process". The process of creativity, or divergent thinking, provides a wide variety of ideas and possibilities which allows the student to choose the most convenient and possible solution. While the process of critical thinking, or a convergent thinking, is providing the tools necessary for evaluation process which would allow it to be effective and at the same time be suitable for the solutions and approaches created or generated in the creative process. The feedback loop of creative and critical thinking becomes a fundamental source in the development of creative projects, and thus it is essential in the education of Arts and Design."

\section{DAVID KOLB'S THEORY OF EXPERIEN- TIAL LEARNING}

As creative thinking improves the ability of creativeness and innovation through cognitive approaches, "Much of Kolb's theory is concerned with the learner's internal cognitive processes." David Kolb published his learning styles model in 1984. This model gave rise to terms such as "experiential learning theory" (ELT), and "learning styles inventory" (LSI). Effective learning is realized when a person pass through a four stage cycle of learning: 1.having a concrete experience followed by 2.observation of and reflection on that experience which leads to 3.the formation of abstract concepts (analysis) and generalizations (con- 
clusions) which are then 4.used to test hypothesis in future situations, resulting in new experiences." (McLeod, S., 2013). Kolb's experiential learning model is a spiral that describes the learning process. Learning can begin at any stage depending on the individual's learning style (i.e., diverging, assimilating, converging, accommodating) but learning will be the most effectively when completing all four stages. Continuing education in spiral process promotes the continuous development of learners' experiences (Kolb,D.A, 1981 and Kolb A.Y. et al., 2013) See figure 1 .
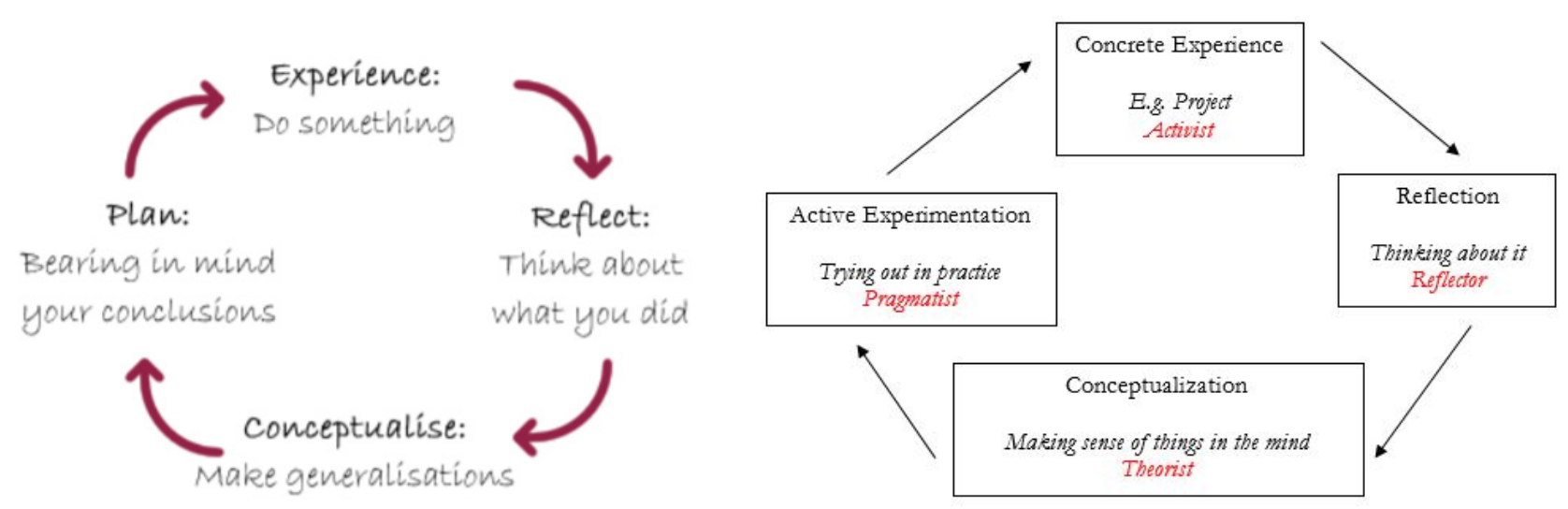

Figure 1. Kolb's experiential learning cycle (McPhent, S., 2017)

\section{THE LEARNING STYLE INVENTORY}

"In 1971 David Kolb developed the Learning Style Inventory (LSI) to assess individual learning styles" (Kolb, D.A.,2001). Kolb's learning theory sets out four distinct learning styles, which are based on a four-stage learning cycle. Various factors influence a person's preferred style as social environment, educational challenges or the basic cognitive structure of the individual. It's often easier to see the construction of Kolb's learning styles in terms of a two-by-two matrix. Each learning style represents a combination of two preferred styles (McLeod, S.,2013) See figure 2.

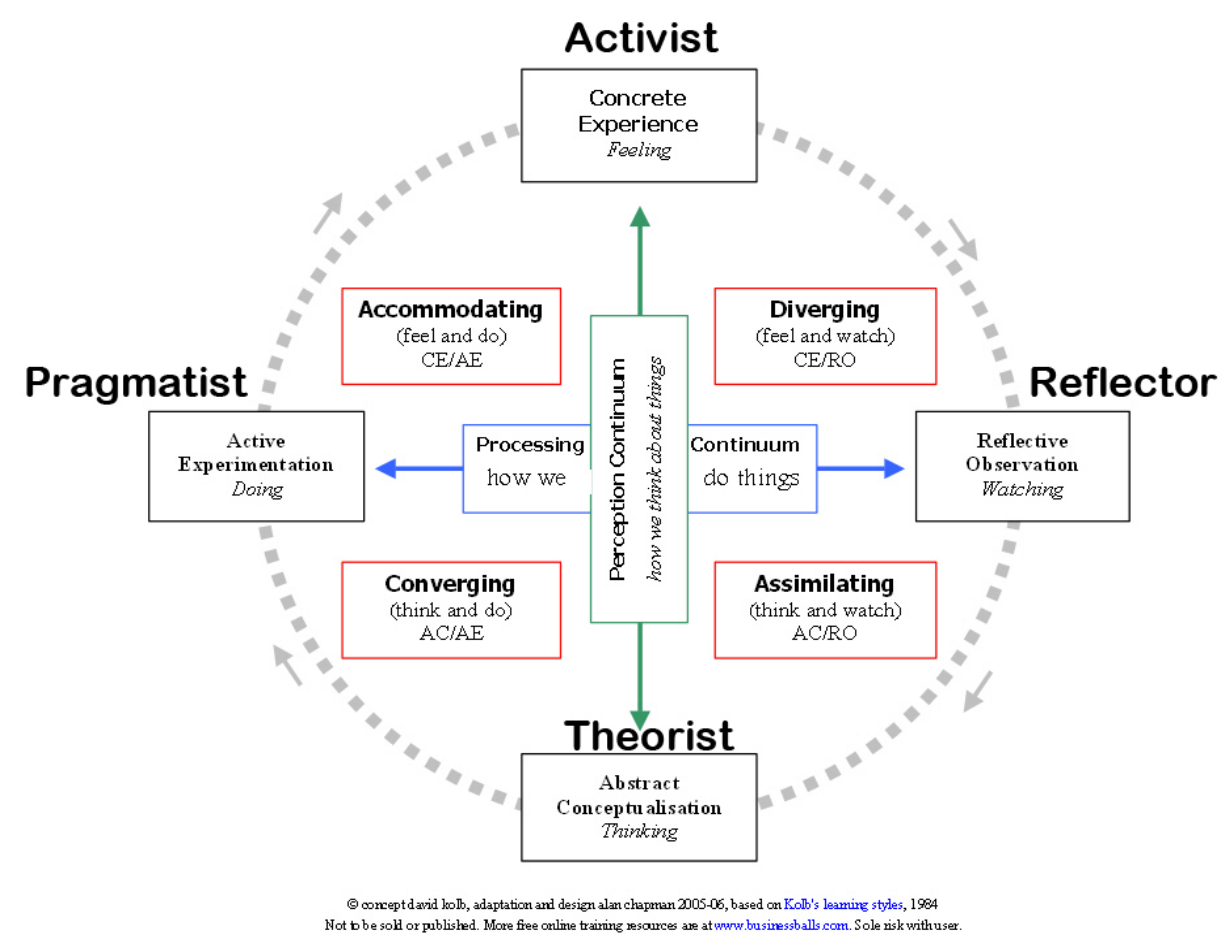

Figure 2. Kolb's experiential learning model (Experiential learning cycle combined with P. Honey and A. Mumford's learning styles) (Chiong,S.,2011)

Note; $\mathrm{CE}$ is Concrete Experience, $\mathrm{RO}$ is Reflective Observation, $\mathrm{AC}$ is Abstract Conceptualization, and AE is Active Experimentation 


\section{- DIVERGING (FEELING AND WATCHING - CE/RO)}

These people are able to look at things from different perspectives. They prefer to watch rather than do, tending to gather information and use imagination to solve problems. Kolb called this style 'diverging' because these people perform better in situations that require ideas-generation, have broad cultural interests, are interested in people, tend to be imaginative and emotional, and tend to be strong in the arts field. People with the diverging style prefer to work in groups.

\section{-ASSIMILATING (WATCHING AND THINK- ING - AC/RO)}

The Assimilating learning preference involves a concise, logical approach. Ideas and concepts are more important than people. These people require good clear explanation rather than a practical opportunity. In formal learning situations, people with this style prefer readings, lectures, exploring analytical models, and having time to think things through.

\section{-CONVERGING (DOING AND THINKING - AC/} AE)

People with a converging learning style can solve problems and will use their learning to find solutions to practical issues, prefer technical tasks, and are less concerned with people and interpersonal aspects, are best at finding practical uses for ideas and theories, like to experiment with new ideas, to simulate, and to work with practical applications.

\section{-ACCOMMODATING (DOING AND FEELING - CE/AE)}

The Accommodating learning style is 'hands-on,' and relies on intuition rather than logic. These people use other people's analysis, and prefer to take a practical, experiential approach. They are attracted to new challenges and experiences, and to carrying out plans. They tend to rely on others for information than carry out their own analysis. This learning style is prevalent within the general population. (Kolb, D.A., 2001)

\section{REFLECTIVE PRACTICE}

Reflective practice is a process that assists the methods of teaching, learning and understanding. This practice has become a focus of interest, a crucial tool and a powerful movement in teacher education. The complexity of teaching requires teachers to question their own methods of their own professional development. This is to improve and increase the learners' performance. Reflective practice is the ability to reflect on an action so as to engage in a process of continuous learning but experience alone does not necessarily lead to learning. People tend to learn from their own professional experiences, rather than from formal taught learning process. It is the most important source of personal professional development and improvement. It is also an important way to bring together theory and practice (Mathew, P. et al, 2017). Schon emphasized on reflective practice as a continuous process that involves the learner to thoughtfully consider their own experience and apply their knowledge to their practice under the supervision of professionals (Schon, D.A,2017). It assists in developing their own personality. It has been suggested that reflective practice develop the analysis of feelings and evaluation of experience (Gibbs, G.,1988).

\section{PROBLEM STATMENT}

Educators are unaware of their students learning styles preferences which maybe a challenge to coop with the process and/or the sequence of a unit course whether in their projects and/or assignments. Students as well as are unaware of their learning style and their strongest learning style preference and how they may develop it to be able to increase their potentials.

\section{AIMS AND OBJECTIVES}

The main purpose of this paper is to investigate the differences between an Art student and a Design student, who are studying in different majors at the Faculty of Arts \& Design; in terms of their learning style preferences and how it affects their capabilities of acquiring knowledge and what the educator should consider as an approach/es needed to meet the students' requirements.

\section{HYPOTHESIS AND METHODOLOGIES}

In this paper, the researchers investigate the necessity of identifying the best/strongest learning preference of each student which will definitely help in acquiring knowledge and progression in the educational process. That goal led us to use Peter Honey and Alan Mumford learning styles questionnaire which is developed upon the work of Kolb. They identified four distinct learning styles or preferences: Activist, Theorist; Pragmatist and Reflector. These are the learning approaches that individuals naturally prefer and they recommend that in order to maximize one's own per- 
sonal learning, each learner ought to understand their learning style, and to seek out opportunities to learn using that style. See figure 2

Researchers apply the questionnaire on students enrolled at the Faculty of Arts \& Design, MSA University from different majors, levels and ranking (GPA) and received 105 responses distributed as follows: 96 are studying in majors, 5 are in foundation year and 4 are graduates. A comparison between the different learning styles of students was executed. The 95 students are studying in the following majors; Interior Design, Fashion Design, Graphics \& Media Arts and
Cinema \& Theatre. It was decided at first to exclude a number of questionnaires that was received from the interior design Dept. in order to have an approximate equal amount of questionnaires in each major to reach more fair creditable results. 77 questionnaires were analyzed and what was found that $56 \%$ of the students prefer one specific learning style (single preference), as shown in figure. 3 , while $26 \%$ of students are double preference in their learning style and the rest $18 \%$ may combine between 3 or 4 different learning styles which was tended to be addressed as multi-preference. See figure. 3

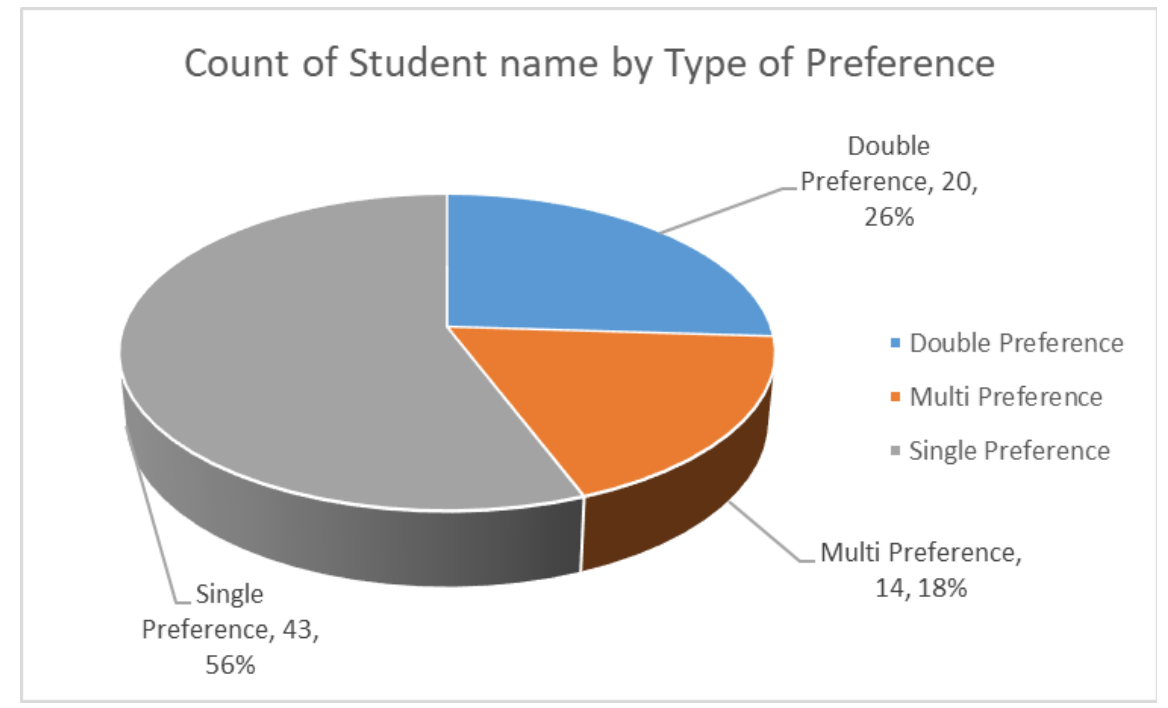

Figure 3. Percentages of students by Preference of learning style

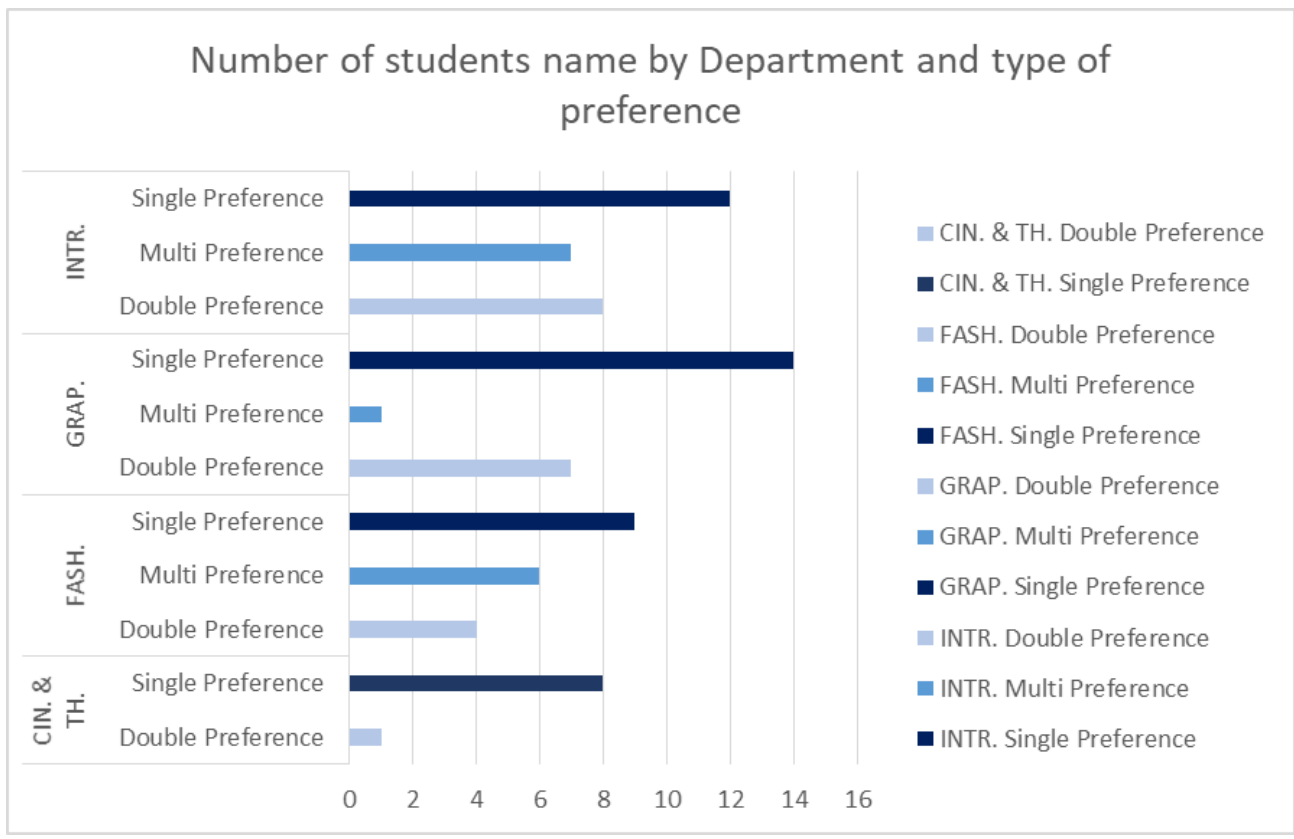

Figure 4. Scheme of Students' predominant preference in different majors

Note; CIN. \& TH. Is Cinema \& Theatre Department, FASH. Is Fashion Design Department, GRAP. Is Graphics and Media Arts Department, and INTR. Is Interior design Department. 
When analyzing the scheme of students' preference in different majors as indicated in Figure 4, it was found that the predominant is the single preference learning style in all majors. Accordingly, the analysis was focused on students with only one preference of learning style, which is the strongest. The following results has been realized, see figure 5; the majority of students studying in the Interior design department tend to be 'Reflectors' with 50\% followed by students whom prefer to be 'Activists', 33.3\%, and the least are the 'Theorists' and the 'Pragmatists' which both are only $8.3 \%$. Students studying in the Graphics and Media Arts, Fashion Design and Cinema \& Theatre, tend to be more of an 'Activist' style learner than any other preference. The analysis shows also no evidence of the 'Pragmatists' learning style among students in the last three majors mentioned.
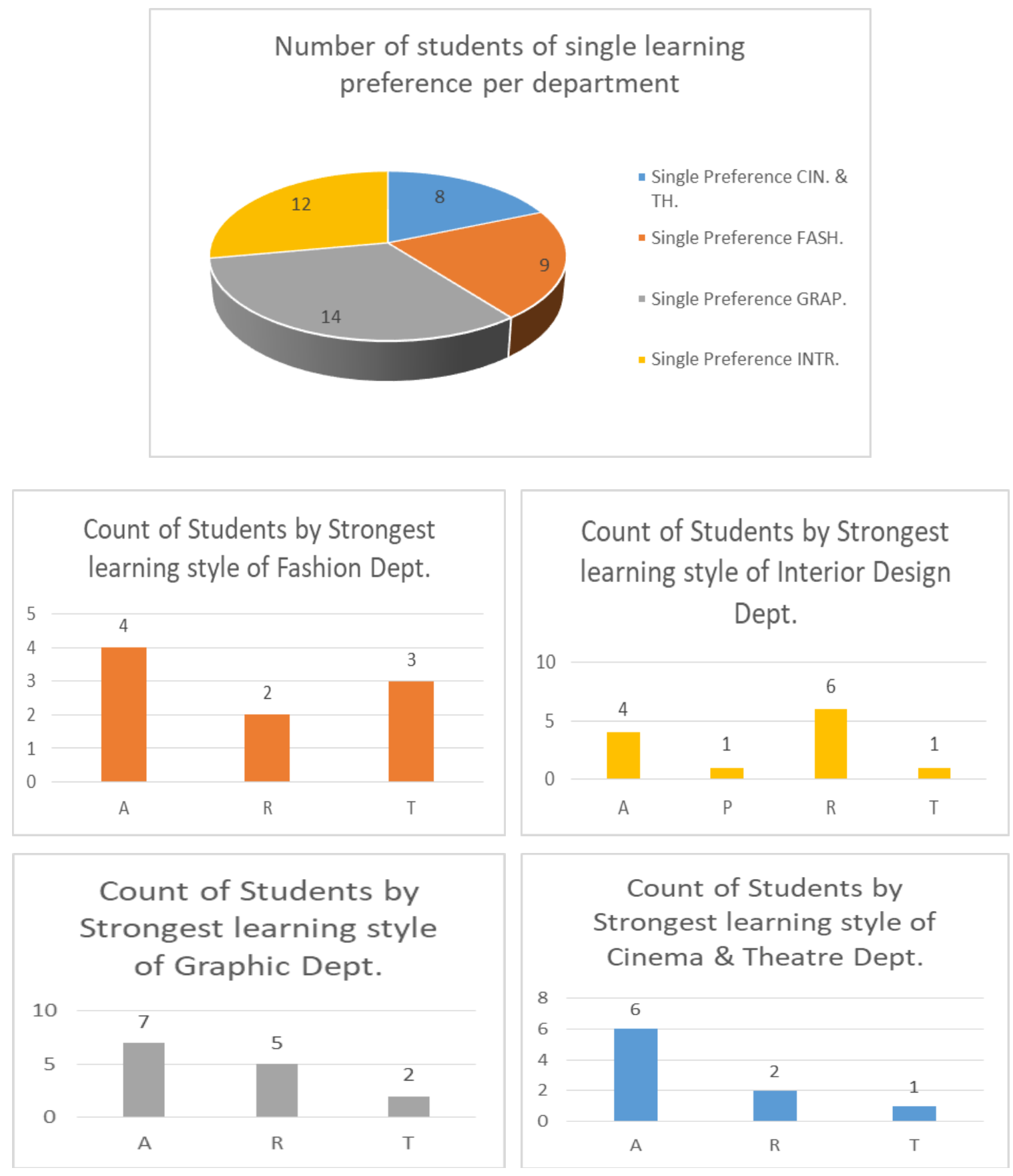

Figure 5. Scheme of Students' strongest preference learning style in different majors 
From figures 3, 4 and 5, the researchers were able to determine the majority of students' preference in each department. But yet students in every school year get to experience different approaches of teaching which may be an influence of change in their ways of thinking and/or learning. In order to see if there were any changes in students' learning style, a questionnaire has been given to a number of students when they were in freshmen year and again after their graduation (5 years apart). In Table 1, a comparison between each student's two questionnaires was analyzed to see if there was any difference in their learning styles. Student A and Students B remained the same while Student C subconsciously changed her learning style while Student D decided to change based on his results and his own statement

\begin{tabular}{l|l|l|l|l|l} 
& $\begin{array}{l}\text { Old } \\
\text { Learning } \\
\text { Preference }\end{array}$ & Level & $\begin{array}{l}\text { New Learning } \\
\text { Preference }\end{array}$ & level & Major \\
\hline Student A & Activist & strong & Activist & strong & $\begin{array}{l}\text { Graphics \& Media Arts- } \\
\text { Art Graduate } \\
\text { (GPA 2.77) }\end{array}$ \\
\hline Student B & Reflector & V.Strong & Reflector & V.Strong & $\begin{array}{l}\text { Cinema \& Theatre } \\
\text { Graduate } \\
\text { (GPA 3.08) }\end{array}$ \\
\hline Student C & $\begin{array}{llll}\text { Activist \& } \\
\text { Theorist }\end{array}$ & Strong & $\begin{array}{l}\text { Theorist } \\
\text { Pragmatist }\end{array}$ & Moderate & $\begin{array}{l}\text { Graphics \& Media Arts- } \\
\text { Art Graduate } \\
\text { (GPA 3.44) }\end{array}$ \\
\hline Student D & Activist & V.Strong & $\begin{array}{l}\text { Reflector } \\
\text { Theorist } \\
\text { Pragmatist }\end{array}$ & $\begin{array}{l}\text { Strong } \\
\text { Graphics \& Media Arts- } \\
\text { Design Student } \\
\text { (GPA 2.77) }\end{array}$
\end{tabular}

Table 1. Students' questionnaire results

\section{CONCLUSIONS}

The majority of the students tend to have a single strong preference in their learning styles but some may adapt and or change their approach to fulfill the requirements they are trying to meet. Most of the Art Students tend to be 'Activists'. Although Interior students and Fashion represent the 'Design' students but yet the Fashion students are mainly 'Activists' while the Interior students are 'Reflectors'. Students' learning preference may change according to various causes which may affect the scale of preference and/or the type of the learning style.

So the researchers recommend that the questionnaire should be applied on freshmen, sophomore, junior and senior students with the aim to have a better understanding of the students' learning styles so that educators could plan a series of solutions and/or approaches that may influence and improve the level of the student.

\section{References}

- Chiong, S., 2011, Feb 2011, Kolb's Learning Styles Model And Experiential Learning Theory, ETEC 510, 20 Feb 2020, http://etec.ctlt. ubc.ca/510wiki/Kolb\%27s_Learning_Styles_ Model_and_Experiential_Learning_Theory.

- Demirbaş, O.O. and Demirkan, H., 2003. Focus on architectural design process through learning styles. Design Studies, 24(5), pp.437-456.

- Demirbas, O.O. and Demirkan, H., 2007. Learning styles of design students and the relationship of academic performance and gender in design education. Learning and instruction, 17(3), pp.345-359.

- Demirbaş, Ö.O., 2001. The relation of learning styles and performance scores of the students in interior architecture education (Doctoral dissertation, Bilkent University).

- Dunn, R. and Dunn, K., 1975. Learning styles, teaching styles. NASSP Bulletin, 59(393), 
pp.37-49.

- Gibbs, G., 1988. Learning by doing: A guide to teaching and learning methods. Further Education Unit.

- Indrasiene, V., Jegeleviciene, V., Merfeldaitè, O., Penkauskiene, D., Pivoriene, J., Railiene, A., Sadauskas, J. and Valaviciene, N., 2019. WHAT CRITICAL THINKING AND FOR WHAT?. SOCIAL WELFARE: INTERDISCIPLINARY APPROACH, 1(9), pp.24-38.

- Kolb, A. Y., \& Kolb, D. A, 2013. Kolb Learning Style Inventory workbook version 3.2, Philadelphia, PA: HayGroup.

- Kolb, D.A., 1981. Learning styles and disciplinary differences. The modern American college, 1, pp.232-255.

- Kolb, D.A., Boyatzis, R.E. and Mainemelis, C., 2001. Experiential learning theory: Previous research and new directions. Perspectives on thinking, learning, and cognitive styles, 1(8), pp.227247.

- Kvan, T. and Jia, Y., 2005. Students' learning styles and their correlation with performance in architectural design studio. Design Studies, 26(1), pp.19-34.

- Mathew, P., Mathew, P. and Peechattu, P.J., 2017. Reflective practices: A means to teacher development. Asia Pacific Journal of Contemporary Education and Communication Technology, 3(1), pp.126-131.

- McLeod, S., 2013. „Kolb-Learning styles ${ }^{\text {ee }}$ Simply Psychology.

- McPhent, S., 2017, Skillshub, What are Kolb's Learning styles and what do they mean?, 29 Feb2020, https://www.skillshub.com/what-arekolbs-learning-styles/

- Montana-Hoyos, C. and Lemaitre, F., 2011. Systems thinking, disciplinarity and critical thinking in relation to creativity within contemporary arts and design education. Studies in Learning, Evaluation, Innovation \& Development, 8(2).

- Newland, P., Powell, J.A. and Creed, C., 1987. Understanding architectural designers' selective information handling. Design Studies, 8(1), pp.216.

- Paul, R. and Elder, L., 2006. The Miniature Guide to Critical thinking. Concepts and tools. Foundation for critical thinking. Dillon Beach, CA. Retrieved Dec, 8, p.2015.

- Schön, D.A., 1987. Educating the reflective prac- titioner.

- Schön, D.A., 2017. The reflective practitioner: How professionals think in action. Routledge.

- Slaats, A., Lodewijks, H.G. and van der Sanden, J.M., 1999. Learning styles in secondary vocational education: disciplinary differences. Learning and instruction, 9(5), pp.475-492.

- Uluoğlu, B., 2000. Design knowledge communicated in studio critiques. Design Studies, 21(1), pp.33-58.

- Waks, L.J., 1999. Reflective practice in the design studio and teacher education. Journal of curriculum studies, 31(3), pp.303-316.

- Waks, L.J., 2001. Donald Schon's philosophy of design and design education. International Journal of Technology and Design Education, 11(1), pp.37-51.

\section{Appendix}

\section{Learning Styles Questionnaire}

Name:

This questionnaire is designed to find out your preferred learning style(s). Over the years you have probably developed learning "habits" that help you benefit more from some experiences than from others. Since you are probably unaware of this, this questionnaire will help you pinpoint your learning preferences so that you are in a better position to select learning experiences that suit your style and having a greater understanding of those that suit the style of others.

This is an internationally proven tool designed by Peter Honey and Alan Mumford.

There is no time limit to this questionnaire. It will probably take you 10-15 minutes. The accuracy of the results depends on how honest you can be. There are no right or wrong answers.

If you agree more than you disagree with a statement put a tick by it.

If you disagree more than you agree put a cross by it. Be sure to mark each item with either a tick or cross. 
1. I have strong beliefs about what is right and wrong, good and bad.

2. I often act without considering the possible consequences

3. I tend to solve problems using a step-by-step approach

4. I believe that formal procedures and policies restrict people

5. I have a reputation for saying what I think, simply and directly

6. I often find that actions based on feelings are as sound as those based on careful thought and analysis

7. I like the sort of work where I have time for thorough preparation and implementation

8. I regularly question people about their basic assumptions

9. What matters most is whether something works in practice

10. I actively seek out new experiences

11. When I hear about a new idea or approach I immediately start working out how to apply it in practice

12. I am keen on self-discipline such as watching my diet, taking regular exercise, sticking to a fixed routine, etc.

13. I take pride in doing a thorough job

14. I get on best with logical, analytical people and less well with spontaneous, "irrational"

15. I take care over the interpretation of data available to me and avoid jumping to conclusions

16. I like to reach a decision carefully after weighing up many alternatives

17. I'm attracted more to novel, unusual ideas than to practical ones

18. I don't like disorganized things and prefer to fit things into a coherent pattern

19. I accept and stick to laid down procedures and policies so long as I regard them as an efficient way of getting the job done

20. I like to relate my actions to a general principle

21. In discussions I like to get straight to the point

22. 1 tend to have distant, rather formal relationships with people at work

23. I thrive on the challenge of tackling something new and different

24. .I enjoy fun-loving, spontaneous people

25. I pay meticulous attention to detail before coming to a conclusion

26. I find it difficult to produce ideas on impulse

27. I believe in coming to the point immediately
28. I am careful not to jump to conclusions too quickly

29. I prefer to have as many resources of information as possible - the more data to think over the better

30. Flippant people who don't take things seriously enough usually irritate me

31. I listen to other people's points of view before putting my own forward

32. I tend to be open about how I'm feeling

33. In discussions I enjoy watching the maneuverings of the other participants

34. I prefer to respond to events on a spontaneous, flexible basis rather than plan things out in advance

35. I tend to be attracted to techniques such as network analysis, flow charts, branching programs, contingency planning, etc.

36. It worries me if I have to rush out a piece of work to meet a tight deadline

37. I tend to judge people's ideas on their practical merits

38. Quiet, thoughtful people tend to make me feel uneasy

39. I often get irritated by people who want to rush things

40. It is more important to enjoy the present moment than to think about the past or future

41. I think that decisions based on a thorough analysis of all the information are sounder than those based on intuition

42. I tend to be a perfectionist

43. In discussions I usually produce lots of spontaneous ideas

44. In meetings I put forward practical realistic ideas

45. 19. More often than not, rules are there to be broken

46. I prefer to stand back from a situation

47. I can often see inconsistencies and weaknesses in other people's arguments

48. On balance I talk more than I listen

49. I can often see better, more practical ways to get things done

50. I think written reports should be short and to the point

51. I believe that rational, logical thinking should win the day

52. I tend to discuss specific things with people rather than engaging in social discussion

53. I like people who approach things realistically rather than theoretically 
54. In discussions I get impatient with irrelevancies and digressions

55. If I have a report to write I tend to produce lots of drafts before settling on the final version

56. $1 \mathrm{am}$ keen to try things out to see if they work in practice

57. I am keen to reach answers via a logical approach

58. I enjoy being the one that talks a lot

59. In discussions I often find I am the realist, keeping people to the point and avoiding wild speculations

60. I like to ponder many alternatives before making up my mind

61. In discussions with people I often find I am the most dispassionate and objective

62. In discussions I'm more likely to adopt a "low profile" than to take the lead and do most of the talking

63. I like to be able to relate current actions to a longer term bigger picture

64. When things go wrong I am happy to shrug it off and "put it down to experience"

65. I tend to reject wild, spontaneous ideas as being impractical
66. It's best to think carefully before taking action

67. On balance I do the listening rather than the talking

68. I tend to be tough on people who find it difficult to adopt a logical approach

69. Most times I believe the end justifies the means

70. I don't mind hurting people's feelings so long as the job gets done

71. I find the formality of having specific objectives and plans stifling

72. I'm usually one of the people who puts life into a party

73. I do whatever is expedient to get the job done

74 . I quickly get bored with methodical, detailed work

75. I am keen on exploring the basic assumptions, principles and theories underpinning things and events

76. I'm always interested to find out what people think

77. I like meetings to be run on methodical lines, sticking to laid down agenda, etc.

78. I steer clear of subjective or ambiguous topics

79. I enjoy the drama and excitement of a crisis situation

80. People often find me insensitive to their feelings

\section{Scoring And Interpreting The Learning Styles Questionnaire}

The Questionnaire is scored by awarding one point for each ticked item. There are no points for crossed items. Simply indicate on the lists below which items were ticked by circling the appropriate question number.

$\begin{array}{rrrr}2 & 7 & 1 & 5 \\ 4 & 13 & 3 & 9 \\ 6 & 15 & 8 & 11 \\ 10 & 16 & 12 & 19 \\ 17 & 25 & 14 & 21 \\ 23 & 28 & 18 & 27 \\ 24 & 29 & 20 & 35 \\ 32 & 31 & 22 & 37 \\ 34 & 33 & 26 & 44 \\ 38 & 36 & 30 & 49 \\ 40 & 39 & 42 & 50 \\ 43 & 41 & 47 & 53 \\ 45 & 46 & 51 & 54 \\ 48 & 52 & 57 & 56 \\ 58 & 55 & 61 & 59 \\ 64 & 60 & 63 & 65 \\ 71 & 62 & 68 & 69 \\ 72 & 66 & 75 & 70 \\ 74 & 67 & 77 & 73 \\ 79 & 76 & 78 & 80\end{array}$

TOTALS

Activist Reflector Theorist Pragmatist 
Learning Styles Questionnaire Profile Based on General Norms for 1302 People

\begin{tabular}{|c|c|c|c|c|}
\hline Activist & Reflector & Theorist & Pragmatist & \\
\hline 20 & 20 & 20 & 20 & \multirow{8}{*}{$\begin{array}{l}\text { Very strong } \\
\text { preference }\end{array}$} \\
\hline 19 & & & & \\
\hline 18 & & 19 & 19 & \\
\hline 17 & & & & \\
\hline 16 & & 18 & & \\
\hline 15 & & 17 & 18 & \\
\hline \multicolumn{4}{|l|}{14} & \\
\hline 13 & 18 & 16 & 17 & \\
\hline \multirow[t]{2}{*}{12} & 17 & 15 & 16 & \multirow{3}{*}{ Strong preference } \\
\hline & 16 & & & \\
\hline 11 & 15 & 14 & 15 & \\
\hline 10 & 14 & 13 & 14 & \multirow{4}{*}{ Moderate } \\
\hline 9 & 13 & 12 & 13 & \\
\hline \multicolumn{4}{|l|}{8} & \\
\hline 7 & 12 & 11 & 12 & \\
\hline 6 & 11 & 10 & 11 & \multirow{3}{*}{ Low preference } \\
\hline 5 & 10 & 9 & 10 & \\
\hline 4 & 9 & 8 & 9 & \\
\hline \multirow[t]{3}{*}{3} & 8 & 7 & 8 & \multirow{9}{*}{$\begin{array}{l}\text { Very low } \\
\text { preference }\end{array}$} \\
\hline & 7 & 6 & 7 & \\
\hline & 6 & 5 & 6 & \\
\hline \multirow[t]{3}{*}{2} & 5 & 4 & 4 & \\
\hline & 4 & 3 & 3 & \\
\hline & 3 & & & \\
\hline \multirow[t]{2}{*}{1} & 2 & 2 & 2 & \\
\hline & 1 & 1 & 1 & \\
\hline 0 & 0 & 0 & 0 & \\
\hline
\end{tabular}

